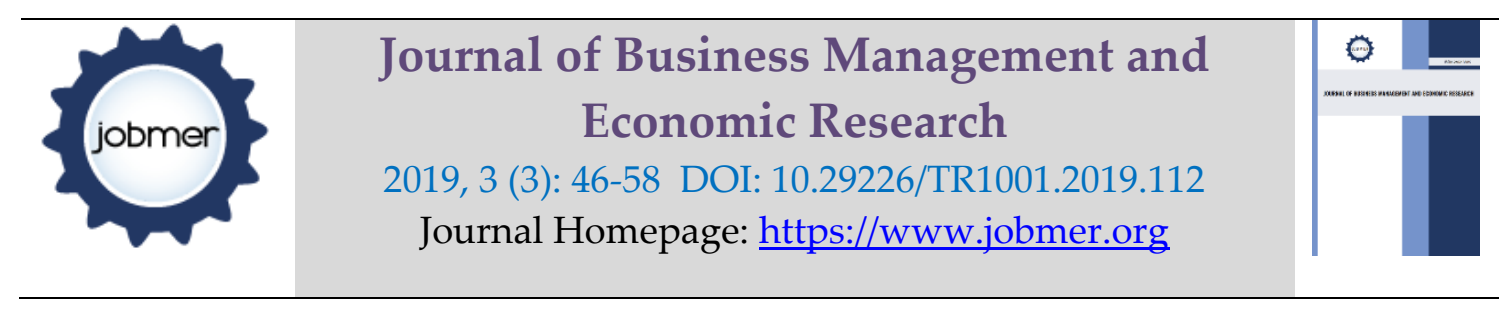

\title{
Ethics of Price Strategies in Business
}

\section{Professor Piotr Masiukiewicz, PhD,}

Institute of Value Management, Warsaw School of Economics, Paweł Dec, PhD,

Institute of Corporate and Investment Finance, Warsaw School of Economics paweldec@gmail.com

\begin{abstract}
Prices decisive it is important area of consumer protection. Law prohibition of use some types of price are make in all development countries (include EU directives and OECD directions). To rank non-ethics prices among the prohibition prices and overmuch high prices. Enterprises and branches have had good praxis's codes (or ethics code) contemporary, unfortunately it hasn't regulation of prices decisive in these codes. In this paper was showed price regulations (include prohibit prices) and case studies of non-ethics and dishonest price praxis in Poland and Europe. Managers hadn't always consciousness for civil and criminal responsibility of faulty prices decisions. It is necessary large education of managers in area of strategies the prices ethics decisive and enforces of ethics codes in enterprises.
\end{abstract}

Keywords: Ethics, pricing strategy, consumer behavior, prohibited prices

\section{Introduction}

Consumer protection issues have been at the center of attention of governments and international organizations for decades. It is also reflected in the regulations of the European Union; an important stage in the development of pro-consumer policy was the inclusion of the principle of consumer protection in the Maastricht European Union Treaty. Several directives and recommendations have been issued in the $\mathrm{EU}$, including the Directive on unfair practices in consumer contracts, the Recommendation on electronic payments, the Consumer Credit Directive, the Directive on cross-border provision of financial services and the Misleading 
advertising directive. Purchasing prices is an important area of consumer protection. Legal prohibitions on the use of certain types of prices occur in all developed countries; the prohibition of the use of such prices as dumping, cartel or transfer is also found in the European Union directives and OECD guidelines. Some legal regulations are not always precise, hence national court judgments and ECJ judgments play a significant role. In practice, however, managers responsible for pricing policy are not always aware of civil and even criminal liability for wrong decisions in this area, the price-making ethics are low. The most important consequence for business - if clients find out about an unfair pricing strategy - is the loss of customers.

The purpose of this article is to identify and assess ethical criteria in the process of price-making in the economy and to analyze the use of priceless prices as unethical decisions. This is in the new concept of price management, called the enterprise price intelligence (Zinoecker, et al., 2012). The study used research methods such as: literature analysis, legal analysis, desk research and case studies.

\section{Basics of ethics in establishing market and official prices}

In every society there are notions of just and unjust prices; it can be accepted as an axiom. However, there are different criteria for including prices in these categories (Carrigan, Attalla, 2001, Heath, 2004, Panwar et al, 2016). Undoubtedly, the prices prohibited by law or usury (in financial institutions) are usually assessed as unfair. In the economy of Islam, the use of all usury is forbidden. Unfair high income is generally associated with unfair pricing in business. The problem of justice in many areas of human activity, discussed for years, in terms of prices on the market (including those stipulated by the state), did not receive wider research and publications; even though it is an important economic and ethical problem in management (Seals, 2018).

In the classical economy, according to J. Galbraith (2011), instead of the alleged competition in a large sector of a modern, highly concentrated economy, it was necessary to assume the existence of a monopoly or something similar (oligopoly) and socially optimal price and production could no longer be found in a competitive market. Some authors, however, saw the necessity of vigorously introducing antiturial laws. There is a constant discussion as to whether the fundamental principles of a market economy may favor the exploitation of a part of society and the enrichment at the expense of the poorest. (Stiglitz, 2018) Hence, regulation of prices in the economy was gradually introduced by governments and parliaments; including particularly sensitive prices (rents, electricity and others). 
The classic market division of price types includes prices based on costs, demand and competition. The second widely used classification is the determination of free (market) and regulated prices (by the state) (Masiukiewicz, 2010). In practice, there are so-called social prices; that is, with the state budget surcharge (for example, some products for babies). Using other classifications, especially from the point of view of the ethical criterion, the following prices are usually included in unethical prices:

- excessively high prices,

- dumped prices (i.e. below cost),

- legally banned prices (cartel prices, bundled prices, transfer prices, discriminatory prices, prices displayed as incomplete, e.g. given without VAT and others),

- multi-component prices,

- media prices (the offer contains so many conditions that less than $0.001 \%$ of potential customers meet them).

Robust price formation as a concept referring to the pricing strategy, was described by B. Lunden (2008). This author believes that the main goal of robbery is not to increase sales, but to weaken another company; even if it means losses in your own company. Such a strategy can be used by large enterprises. Of course, it is important to have a good power stay so that it can survive the competitive struggle; and the method is usually the use of dumped prices.

It is quite common practice to enter the market with a new product or an old product, but to a new market using a promotional price. Such prices are usually much lower than those offered by competitors; Of course, it's about getting customers. After a period of taming customers with a new product, prices are usually raised to the "normal" level. However, the strategy of low prices may in this case be divided into stages to varying degrees. A sudden increase in prices after a short promotional period is usually badly received by customers, unless they are previously warned about it. A change in the pricing strategy usually has an ethical context. Hence, rapid price changes, especially price increases, bear a strong negative ethical context that can sometimes threaten the reputation of a given brand. Therefore, any price increase or even a price reduction of products should be analyzed in detail from the point of view of the ethical context and the company's ethical code (Matusiak, 2018).

There is, of course, a category of prices for new products, which is sometimes very high in the first period of production and sale of goods, and it is not ethically reprehensible. In Poland, the Act of 23.08.07 on Counteracting Dishonest Market Practices in a small scope refers to the 
establishment of prices. Market practice is a misleading act if the action in any way causes or can cause the average consumer to take a contractual decision that he would not otherwise have taken. A misleading action may concern: the price, the method of calculating the price or the existence of a specific price advantage. Market practice is considered misleading if it omits relevant information needed by the average consumer to make a contractual decision and thus causes or may cause the average consumer to take a contractual decision that he would not otherwise have taken. The quoted law prohibits the presentation of the product as "free", "free", "free" or similar, if the consumer must pay any amount, except for direct costs related to the response to market practice, receipt or delivery of the product.

The EU Directive on misleading advertising refers, inter alia, to such unfair market practices as:

- using the so-called in advertising media prices,

- providing incomplete prices (e.g. interest on the loan, without specifying fees and commissions, cheap airline ticket prices - no additional fees, etc.),

- presenting outdated prices,

- increasing prices to quickly lower them and display high price cuts,

- other manipulations of price information. Nowadays an important problem is the loss of the ability to deliberately shape prices by some companies. The conscious creation of pricing strategies is defined as price intelligence. Price intelligence is based on the assessment of customer price perception, evaluation of competition pricing strategies, assessment of commodity levels, legalization of price setting and is undoubtedly one of the key factors determining the profitability of an enterprise (Zinoecker, et al., 2012). Unfair pricing, profitability at any price can result in a high level of "rejection of prices" by customers and migration of customers to other sellers (service providers).

Possibilities to avoid criminal sanctions increase the likelihood of unethical acts and creating dishonesty potential in pricing. According to the president of one of the American corporations, Jon Huntsman (2005): Earning money is now simpler than ever. Ignoring traditional moral values too. This leads to disturbing questions: why liaring, cheating, over-interpreting regulations and emerging from fulfilling the obligations included in the contracts have become rooted in society to such an extent? How did it happen that the goal - to achieve material success, began to sanctify all means? Answers can be found in the level of ethics, acceptance of unethical behavior and preferred values in management. 
Every self-respecting company and industry today have codes of good practice or ethical codes; however, was there room for price setting issues? This is important because, according to the economy, the goal of enterprises is to achieve profit and increase shareholder value. Is it irrelevant in this case to comply with ethical principles and, accordingly, all ethically unacceptable methods? The essence of codes is that they are not norms imposed by law or other generally binding regulations but are established by the entrepreneurs themselves or their associations (the so-called self-regulatory system). Consumers perceive such codes as quality marks (meeting certain quality standards of the service), which increases trust in the entrepreneur signatory to such self-regulation.

Unfair market practices, in the light of statutory regulations, under all circumstances are the following misleading market practices:

1. Information provided by the entrepreneur that he has committed to comply with the code of good practice if this is not true;

2. Using a certificate, a quality mark or an equivalent designation without having the right to do so;

3. The statement that the code of good practice has been approved by a public authority or other body if it is not true.

So unfair practices, including PR and advertising, used among companies engaged in competitive wars for market share (including price wars), as well as among financial institutions, caused interest in European Union bodies in this issue (Masiukiewicz, 2015, Ackerlof, Shiller 2015) A directive on unfair commercial practices applied by enterprises to consumers in the internal market was issued, and Member States were required to implement the directive under national law (Directive, 2005).

In many codes, there is no reference to pricing strategies, but there are good exceptions. For example, Danone expects its Code of Ethics to be unified across the entire holding, for example in price reconciliation. Leroy Merlin's chain of construction and decorative stores in sales and marketing policy is based on honest information about products and prices.

The problem of social acceptance of prices (mainly regulated prices) was quite strong in the socialist economy; causing mass protests of workers. Nowadays, assimilation or rejection of prices by consumers is the result of both the level of income and, on the other hand, heuristics 
and shopping attitudes. A new problem requiring research is shaping price strategies by ethical and socially responsible companies (CSR).

\section{Price-making ethics in Islamic economics}

The Islamic economy, based on sharia law, enforces a different approach to price-making in business. The sector of enterprises based on Sharia law is constantly developing in Muslim countries. According to Islamic philosophy and religion, running a business should be transparent, honest, ethical and not based on exploitation, supporting the development of the economy. An important feature of the banks' offer is targeting it not only to Muslims but also to other communities. The basic principles of sharia law are riba, gharar, maysir and guimar (ElGamal, 2006). The guimar principle means the prohibition of exploitation in all forms; therefore, the prices set by the seller should include fair profit and not excessively high. It is the duty of enterprises and citizens to support the poorest through donations (zakat). In some countries, zakat has been raised to the status of a state tax. The Sharia principles apply to all enterprises, including financial ones, which were established and operate as Islamic institutions. Islamic enterprises also implement corporate social responsibility programs. Many Islamic economists believe that Islamic economics is more ethical than conventional economics. Certainly, sharia law rules require managers to have a more moral approach to business, including price setting.

\section{Regulations for forbidden prices}

Legal prohibitions on the use of certain prices are found in all developed countries; the prohibition of using such prices as dumping, cartel or transfer occurs in the European Union directives (Fig. 1). However, always the final assessment of whether the price is forbidden and constitutes a crime belongs to the court. Misleading prices are a false presentation of the essence of the prices of products sold. These are, for example, prices without VAT, transfer prices, price discrimination, prices quoted as incomplete (for example, not giving commission, as part of the multi-component loan price, but only its interest rate) (Masiukiewicz, 2016). 
Figure 1. Types of prohibited and unethical prices - authors proposal

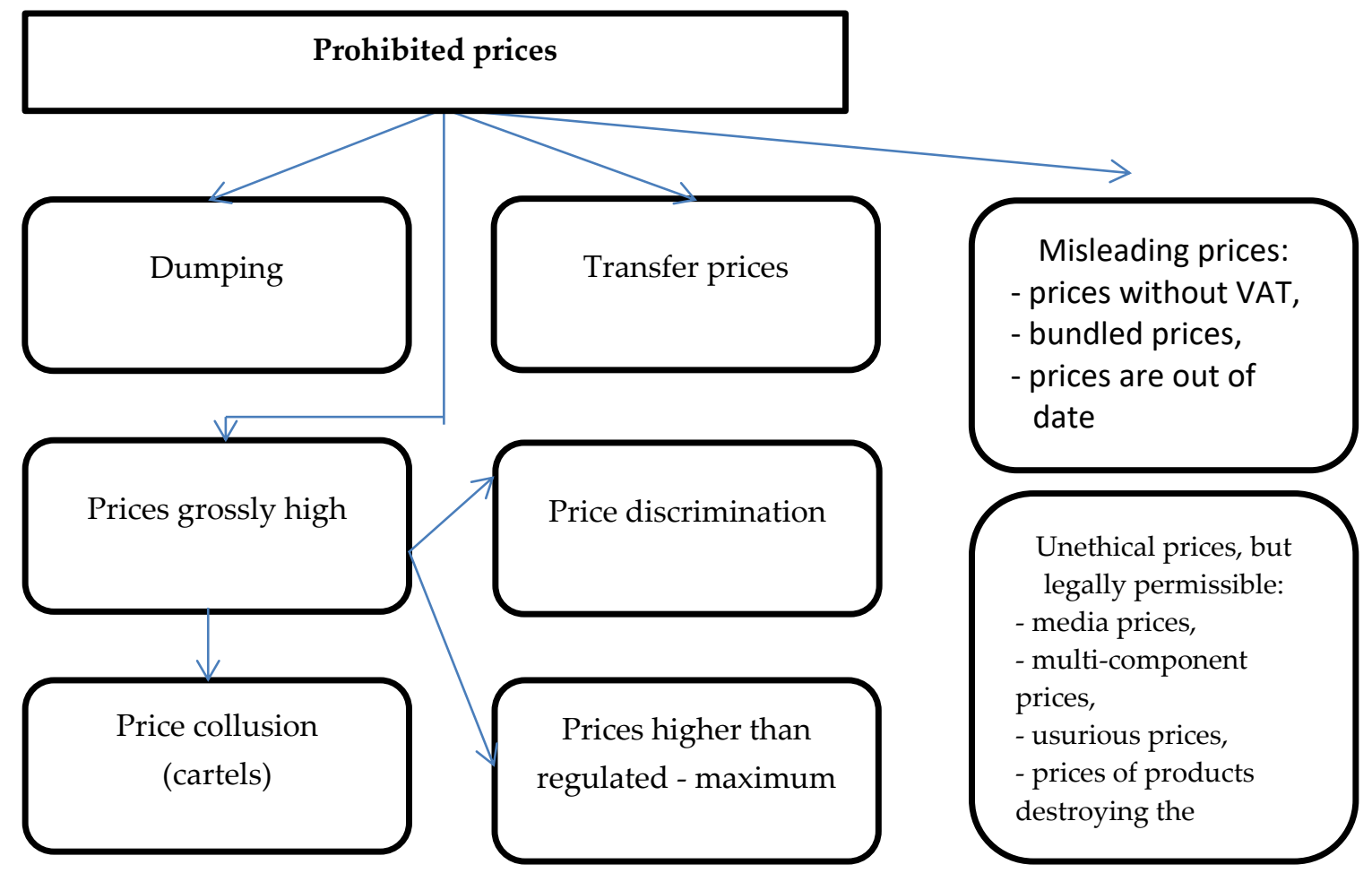

Price discrimination means applying different prices to the same product under comparable sales conditions for different consumer groups. In many countries, these practices are prohibited. For example in the USA - setting different prices for purchasers of the same product (discriminatory prices, e.g. higher for customers with a different skin color), counteracts the so-called the Robinson-Patman Act (adopted already in the 1930s). Multi-component prices are not formally banned, however, they often mislead customers (low-cost airline tickets, banking services and others). To protect bank clients, the European Union introduced consumer credit regulations, including the obligation to provide the customer with a real interest rate (APRC). (Directive, 2014). A separate research problem is unethical marketing; based on unreliable price information (Drapińska, 2015). The institutional system of consumer protection should counteract the above bad practices, unfortunately it is not always effective.

\section{Prices and ethics - research}

Below are presented studies related to the problem of pricing in Poland in the context of ethical attitudes of managers and clients. Over $1 / 3$ of managers surveyed (slightly less in the public 
sector) in Poland believed that only economic values are important in management (Table 1), for this group, pricing strategies are probably only an income creation instrument.

Table 1. Ranks of individual groups of values depending on the type of organization (in answer)

\begin{tabular}{|l|l|c|c|c|c|}
\hline No. & \multicolumn{1}{|c|}{$\begin{array}{c}\text { The importance of a given group of } \\
\text { values }\end{array}$} & $\begin{array}{c}\text { Listed } \\
\text { companies }\end{array}$ & $\begin{array}{c}\text { Other } \\
\text { enterprises }\end{array}$ & $\begin{array}{c}\text { Public } \\
\text { sector }\end{array}$ & Total \\
\hline 1. & $\begin{array}{l}\text { The most important are economic } \\
\text { values, in addition to respect for the } \\
\text { law }\end{array}$ & 35,8 & 32,5 & 24,5 & 32,6 \\
\hline 2. & $\begin{array}{l}\text { Economic values are of key } \\
\text { importance to us, and respect for the } \\
\text { law, ethical standards and good } \\
\text { manners are of key importance }\end{array}$ & 57,5 & 56,8 & 51,0 & 56,4 \\
\hline 3. & $\begin{array}{l}\text { Non-economic values - ethical, } \\
\text { cultural, civic, related to } \\
\text { development, ecology - are } \\
\text { considered to be equally important in } \\
\text { Poland; none of the value groups is } \\
\text { prioritized }\end{array}$ & 6,0 & 10,3 & 20,4 & 10,2 \\
\hline 4. & Other answers & 0,7 & 0,3 & 4,1 & 0,8 \\
\hline & Total & 100,0 & 100,0 & 100,0 & 100,0 \\
\hline
\end{tabular}

Source: (Zarzadzanie, 2016)

In Poland, the index of acceptance of unethical financial behavior is quite high, which probably also translates into low business ethics in price management (Table 2).

Table 2. Index of acceptance of unethical financial behavior in Poland

\begin{tabular}{|l|l|l|}
\hline Year & Index in points & Remarks \\
\hline 2016 & 23,2 & Index developed by \\
2017 & 21,7 & prof. A. Lewicka- \\
2018 & 23,2 & Strzałecka \\
\hline
\end{tabular}

Source: (Raport KPF, 2018)

Are customers willing to pay higher prices for ethical companies? The data leave no illusions, as $60 \%$ of respondents said they would not pay more for products of a company that is ethical and only $20 \%$ of Poles would be willing to pay $5 \%$ to $10 \%$ more for ethical products (Etyka, 2018). Only $5 \%$ of people would pay over $10 \%$ more for products offered by an ethically-progressing company. Thus, when more than half of the respondents were concluded, they noticed a 
deterioration in quality and service standards in the Polish business, but this knowledge did not put on specific customer choices.

In turn, the results of research conducted by the Institute for Sustainable Development indicate that although $60 \%$ of respondents declare their respect for the activities of environmentalists, $70 \%$ understand the necessity to look for alternative solutions to the shrinking resources of natural resources, and $80 \%$ describe their behavior as pro-ecological, also during shopping price wins with ethics among $80 \%$ of respondents. (Etyka, 2018) Moreover, only environmentally friendly production methods were valid for $5 \%$, and $1.6 \%$ of respondents were interested in the type of packaging. Not only do you choose ethical and environmentally friendly products - do not know the customers of specific brands offering products of this type, although more and more companies in advertising campaigns pay attention to ethics. Still, companies still want to reach consumers using these assets.

\section{Unethical price decisions. Case studies}

\subsection{Price cartel of precious metals}

Price collusions (cartels) are difficult to detect in practice; usually cartel participants are very loyal to each other, and minor deviations from the confidential price of a given item precipitate arguments with the competition authorities. Seven Swiss banks probably formed a cartel and set prices for precious metals: gold, silver, platinum and palladium. The Swiss Competition Commission (national government body) opened an investigation into the unlawful pricing of precious metals by banks on the Swiss market. Proceedings are another effect of controlling banks that have tried to circumvent the law. It was about two Swiss financial institutions UBC and Julius Baer and five foreign banks: HSBC, Deutsche Bank, Barclays, Morgan Stanley and Mitsui Bank. They were to contain illegal agreements on precious metal prices. The Swiss office also suspected that some banks could also determine the amount of currency spreads (Collusion, 2015).

Banks were punished with up to 10 percent penalty. annual revenues. The exact losses caused by the illegal price collusion of banks are not yet known; it can be assumed that they will be millions of Swiss francs. 


\subsection{Unethical price of a bank loan}

Banks also offer dishonest and unethical price information. Despite the high inflated prices, due to the low financial education of the society, there is such an offer of buyers. An example was the offer of PKO BP (the Polish government is its strategic owner) in 2016. The bank offered a consumer loan with an interest rate of $1 \%$. The advertisement of this product was intense (TV, press, leaflets). However, in small print, it was reported that the interest rate is 0.5 years, the commission is $9.99 \%$. The total cost of this loan for the customer expressed in the real value of the APRC amounted to $45.75 \%$ p.a., in the situation when deposits were received at that time by most banks at $1-2 \%$. After several months, the offer was withdrawn. This is an example showing that some bank managers still have a serious problem with business ethics, even sui generis in state financial institutions (Dec, Masiukiewicz, 2016).

\subsection{Drugs from Turing Pharmaceuticals}

Information about paramedical services (and proprietary medicines) provided by swindlers, overpriced drug prices, and harmful pharmaceuticals is constantly appearing (Masiukiewicz, 2018). Akerlof and Shiller point out that the FDA (governmental agency of medicines in the USA) is exposed to fraudulent tricks from pharmaceutical companies; leaving them five degrees of freedom in conducting clinical trials and in presenting their results; this system is inefficient (Ackerlof, Shiller, 2015). A loud example of the entrepreneur's decline in business was the case of Martin Shkreli, manager and owner of the pharmaceutical company Turing Pharmaceuticals in the USA. In 2015, he decided to raise the price for a daraprim tablet from 13.5 to 750 USD (Strawinski, 2016). "We have to start making money on this drug" explained the 55-fold increase in the price of the drug used in the treatment of people with AIDS, which is exhibited only in the US about 9,000. prescriptions a year (Kościelniak, 2015). Daprim was included by the WHO on the list of basic medicines, which means that it should be easily available in terms of quantity and price. On the argument raised by the media, low production costs (USD 1 per tablet) in response, the manager pointed to other costs. The media gave him some negative nicknames (embodying everything bad in capitalism, a morally fallen sociopath). Against such a drastic increase, the medical community has argued, arguing with the good of patients, as well as other pharmaceutical manufacturers, not wanting the industry to be perceived as soulless and greedy. The media at the same time showed the manager's lavish lifestyle - ridiculing his arguments. Eventually, Shkreli reduced the price of the drug for hospitals, but only up to $\$ 375$. At the end of 
2015. the manager was detained by the FBI on suspicion of incompatible actions with the law in another of his company (Clifford, Moynihan, 2017) but this did not change the pricing policy of the daraprim drug. The free drug market has its own rights, but this example shows how dangerous a monopoly can be. Taking a deontological perspective, it can be concluded that the decision of Turing Pharmaceuticals was lawful, but people who were ill with their dignity were robbed, perhaps health insurance loans were made. The rich manager showed his indifference towards society. Such a high price of the product acquired because of the disease is far from supported by the ethical theory of deontology - the concept of a fair pricing policy.

\section{Conclusion}

Price-setting ethics is important both for the competitive position of companies and for relations with stakeholders; including based on corporate social responsibility programs. Unethical prices include both legally banned prices as well as excessively high prices and misleading prices. Therefore, the category of socially responsible prices can be introduced to the discussion. This is especially important in sensitive price segments (food, medicines and others). Managers responsible for pricing policy, however, are not always aware of civil and even criminal liability for wrong decisions in this area. Instruments of influence on ethical pricing must be adapted to the specifics of the industry and may include, for example: monitoring of price strategies in large and medium-sized companies, enforcement of the provisions of business ethics codes, media pressure, stigmatizing negative cases of unethical prices, exclusion from contests and prizes of entrepreneurs using unethical prices or introduction of the discussed problem to the training programs and studies for managers. Price strategies in ethical and CSR enterprises are important - they should be monitored in this respect. The customer behavior is still another issue, because even the best company and the code of ethics implemented by it and respected will not affect the behavior of customers seeking simply lower prices. Educating clients, and even earlier younger people, at the school stage must involve shaping ethical attitudes and awareness of their importance. It should be remembered that enterprises operate in a competitive environment and strive to maximize profits and achieved value, and it is not their task to raise clients. This task is on the side of the state and non-governmental organizations. In the era of ubiquitous Internet, the amazing interaction of social media, coordinated actions are necessary so that the ethical attitudes and behaviors of companies do not become a museum exhibit, but the 
need for action on a larger scale. Not only through legal regulations, but also creating a long-term model of education and awareness in these areas.

\section{References}

Akerlof, G. A. Shiller, R. J. (2015). Phishing for Phools. The Economics of Manipulation and Deception. New Jersey: Princeton University Press.

Carrigan, M., Attalla, A. (2001). The myth of the ethical consumer-do ethics matter in purchase behaviour?. Journal of consumer marketing, 18(7), 560-578.

Clifford, S., Moynihan, C. (2017). Martin Shkreli is found guilty of fraud. New York Times.

Kodeks Etyczny Danone. Retrieved from http://www.zywiec-zdroj.pl/kodeks-etyczny.

Dec, P., Masiukiewicz, P. (2016) Odpowiedzialność menedżerów. Warszawa: Wydawnictwo Instytutu Organizacji i Zarządzania w Przemyśle „ORGMASZ”.

Drapińska, A. (20150. Etyka marketingu - czy marketing jest etyczny? Zeszyty Naukowe US. Problemy Zarządzania, Finansów i Marketingu, 875 (41).

Directive 2014/17/EU of the European Parliament and of the Council of 4 February 2014 on credit agreements for consumers relating to residential immovable property and amending Directives 2008/48/EC and 2013/36/EU and Regulation (EU) No 1093/2010.

El-Gamal, M. (2006). Islamic Finance. Law, Economics and Practice. New York: Cambridge University Press.

Etyka i ochrona środowiska przegrywają z ceną - zakupy Polaków. Retrieved from http://www.zielonecieplo.eu/Akt.../Etyka-i-ochrona-srodowiska-przegrywaja-z-cen.

Galbraith, J. K. (2011). Ekonomia w perspektywie. Warszawa: Polskie Towarzystwo Ekonomiczne.

Heath, J. (2004). A market failures approach to business ethics. In The invisible hand and the common good. Berlin, Heidelberg: Springer.

Huntsman, J.M. (2005). Zwycięzcy nie oszukują. Gliwice: Wydawnictwo Helion.

Jabłoński, M., Lewandowska-Nobis, M. (2018). Intencje zarządcze a etyka w kształtowaniu modeli biznesu. Ekonomika i Organizacja Przedsiębiorstwa, 5.

Kościelniak, P. (2015). Awantura o ceny leków, Rzeczpospolita.

Krzyminiewska, G. (2018). Etyczne aspekty funkcjonowania rynku finansowego. Przykład spekulacji surowcami rolnymi. Retrieved from http://cejsh.icm.edu.pl/cejsh/16_05.pdf.

Lunden, B. (2008) Prissattning, Stockholm: Bjorn Lunden Information AB.

Masiukiewicz, P. (2000). Ograniczenia konkurencji cenowej na rynku usług bankowych. Prakseologia. PAN. 140.

Masiukiewicz, P., (2015). Nadużycia w działalności przedsiębiorstw. Aspekty międzynarodowe. Zarządzanie. Zeszyty Naukowe Wyższej Szkoły Humanitas, 4.

Masiukiewicz, P. (2016). Consumer Protection in Financial Services. Prices Area. Eureka: Social and Humanities, 4.

Masiukiewicz, P. (2018). Appropriation Economics versus Managers' Ethics. Journal of Applied Management and Investments, 7(3).

Masiukiewicz, P. (2018). O etyce stanowienia cen. Prakseologia i Zarządzanie, 2.

Matusiak, M. (2018). Zagrożenia prowadzące do nieetycznych strategii, Retrieved from http:// www.log24.pl/artykuly/zagrozenia-prowadzace-do-nieetycznych-strategii,236.

Maziarz, M. (2018). Zarządzanie aktywami. Obowiązek moralny a prawo. Retrieved from http:// zbp.pl/public/Zarzdzanie_aktywami._Obowizek_moralny_a_prawo.pdf. 
Panwar, R., Nybakk, E., Hansen, E., \& Pinkse, J. (2016). The effect of small firms' competitive strategies on their community and environmental engagement. Journal of Cleaner Production, 129, 578-585.

Raport KPF (2018). Moralność płatnicza Polaków. Edycja III. Retrieved from http://www.egospodarka.pl/142563,nieetyczne-zachowania-finansowe.

Seals, G. (2013). An Ethics Paradigm for the Service Organization. American International Journal of Social Science, 2 (3).

Stiglitz, J. E. (2105). Cena nierówności. Warszawa: Wydawnictwo Krytyki Politycznej.

Strawiński, P. (2016). Martin Shkreli. Najbardziej znienawidzony człowiek w Ameryce. Forbes, 09.02.

Uczciwa reklama - granice etyki, moralności i normy prawne w reklamie (2018). Retrieved from http:// www.pi.gov.pl/PARP/chapter_86197.

Uczciwość w świecie finansów. (2004) W. Gasparski (ed). Warszawa: Wydawnictwo Wyższej Szkoły Przedsiębiorczości i Zarządzania im. Leona Koźmińskiego.

Ustawa z 23.08.2007 o przeciwdziałaniu nieuczciwym praktykom rynkowym, Dz.U. 2007 nr 171 poz. 1206.

Zinoecker, R., Nowak, T., Świętek, G. (20012). Budowanie inteligencji cenowej. Harvard Business Review Pl, 2.

Zmowa banków (2015). Ustalały ceny metali szlachetnych. Retrieved from http://wyborcza.biz/biznes/1,100896,18925447,zmowa-bankow.

Zsolnai, L. (2018). Market Fundamentalism versus Responsible Economizing. Praxiology. The International Annual of Practical Philosophy and Methodology. ed. W. Gasparski, 25. 